\title{
An Evidence for Regulatory Cross-Talk between Aryl Hydrocarbon Receptor and Glucocorticoid Receptor in HepG2 Cells
}

\author{
Z. DVOŘ́́K ${ }^{1}$, R. VRZAL ${ }^{1}$, P. PÁVEK ${ }^{2}$, J. ULRICHOVÁ $^{1}$ \\ ${ }^{1}$ Department of Medical Chemistry and Biochemistry, Faculty of Medicine and Dentistry, Palacký \\ University Olomouc, ${ }^{2}$ Department of Pharmacology and Toxicology, Charles University in Prague, \\ Faculty of Pharmacy in Hradec Králové, Czech Republic
}

Received January 29, 2007

Accepted April 30, 2007

On-line May 30, 2007

\section{Summary}

Aryl hydrocarbon receptor (AhR) and glucocorticoid receptor (GR) play crucial role in the regulation of drug metabolizing enzymes and in many essential physiological processes. Cellular signaling by these receptors shares several functional and regulatory features. Here we investigated regulatory cross-talk between these two receptors. Human hepatoma cells (HepG2) were the model of choice. We analyzed the effects of dexamethasone (DEX) and dioxin (TCDD) on i) expression of AhR and GR $\alpha$ mRNAs; ii) levels of $A h R$ and GR proteins; iii) transcriptional activities of AhR and GR in reporter assays; iv) 7-ethoxyresorufinO-deethylase activity (EROD). We found that both DEX and TCDD affected AhR and GR mRNAs expression, proteins levels and transcriptional activities in HepG2 cells. These effects on cellular signaling by AhR and GR comprised up-/down-regulation of gene expression and ligand-dependent protein degradation. We conclude that interactive regulatory cross-talk between GR and AhR receptors in HepG2 cells defines possible implications in physiology and drug metabolism. Future research should be focused on the investigation of AhR-GR cross-talk in various normal human cells and tissues both in vitro and in vivo.

\section{Key words}

Cellular signaling • Nuclear receptors • Xenobiotics • Dioxin • Glucocorticoids • Transcriptional control

\section{Corresponding author}

Zdeněk Dvořák, Institute of Medical Chemistry and Biochemistry, Faculty of Medicine, Palacký University Olomouc, Hněvotínská 3, 77515 Olomouc, Czech Republic. Fax: ++420-58-5632302. E-mail: moulin@email.cz

\section{Introduction}

Nuclear receptors are distantly related regulatory proteins that share certain similarities in terms of subcellular localization, translocation requirements, DNA binding site sequences, and co-activators. A subordination exists between certain members with possible participants, as yet unidentified, that have a role in constituting a tangle of receptor network within a particular cell type (Pascussi et al. 2003, Dvořák et al. 2005 b). Only a limited number of receptors are involved in xenobiotic metabolism. Considerable knowledge is available in the role of pregnane $\mathrm{X}$ receptor (PXR), constitutive androstane receptor (CAR), and aryl hydrocarbon receptor (AhR) in drug metabolism. The role of other nuclear receptors or ligand-activated transcriptional factors in the biotransformation enzymes expression is still under intense investigations. Namely retinoic $X$ receptor $(R X R)$, farnesyl $X$ receptor (FXR), liver $X$ receptor (LXR), vitamin $D$ receptor (VDR), and glucocorticoid receptor (GR) were found to influence xenobiotics metabolizing enzymes expression. The crosstalk between typical xenoreceptors and several endogenous receptors was described by Pascussi et al. (2004). Within this ingenious signaling network, the putative interaction between $\mathrm{AhR}$ and GR receptors seems to be of certain superiority, because the expression of several receptors such as RARs, RXRs, PXR, CAR etc. is subject of regulation by AhR or GR (Pascussi et al. 2003, 2004, Dvořák et al. 2005a).

The information on possible interactions between AhR and GR receptors in terms of cellular 
signaling and regulation of drug metabolizing enzymes are ambiguous. Several lines of evidence indicate that AhR and GR could influence reciprocally each other both in vivo and in vitro. Very first investigations focused on the comparison of molecular, structural and physico-chemical properties of the two receptors indicated that there are certain similarities (Cuthill et al. 1987, Denis et al. 1988, 1989). Further papers deal with the effects of corticoid administration and exposure to dioxin on the induction of cleft palate in mammalian embryos (Pratt 1985, Abbott 1995, Abbott et al. 1994, 1998, 1999). Several in vivo studies described the influence of TCDD administration on GR content and activity (Csaba et al. 1991, Lin et al. 1991, Mizuyachi et al. 2002, Aluru and Vijayan 2004, Aluru et al. 2005).

The data on possible cross-talk between AhR and GR in vitro are much more controversial than those in vivo. First indication that GR could modulate activity of AhR and vice versa comes from the observation that glucocorticoid dexamethasone (DEX) enhances TCDDinducible expression of CYP1A protein and catalytic activity (EROD) in hepatocellular carcinoma cells from a fish Poeciliopsis lucida (Celander et al. 1996). Similarly, the study on H4IIE rat hepatoma cells demonstrated that TCDD-dependent CYP1A1 induction is augmented by dexamethasone. This potentiation was found to depend on posttranscriptional processing (Lai et al. 2004). Synergistic effects of DEX on TCDD-dependent activation of AhR were reported by several other authors (Mathis et al. 1986a,b, Hines et al. 1988). Contrary, TCDD-inducible induction of CYP1B1 mRNA in mouse mammary fibroblasts was suppressed by DEX (Brake et al. 1998).

The aim of this work was to confirm the existence of cross-talk between AhR and GR in vitro. Human hepatoma cells (HepG2) were chosen as the model of choice for this pilot study because i) These cell line is of human origin, and ii) HepG2 cell line is equipped at least with functional endogenous $A h R$ and perhaps GR. The effects of DEX and TCDD on AhR and GR were assessed as i) expression of AhR and GR $\alpha$ mRNAs, ii) the levels of AhR and GR proteins, iii) transcriptional activity of AhR and GR in reporter assay in transiently transfected cells; and iv) 7-ethoxyresorufin- $O$-deethylase activity (EROD). We used single concentrations of DEX $(100 \mathrm{nM})$ and TCDD $(5 \mathrm{nM})$ in the experiments, ensuring saturation of GR and AhR receptors, respectively.

\section{Methods}

\section{Chemicals}

Dulbecco's modified Eagle's medium, fetal calf serum, penicillin, streptomycin, L-glutamine, nonessential amino acids, sodium pyruvate, dicumarol, 7-ethoxyresorufin, dexamethasone, Triton X-100, and Kodak X-Omat AR photographic film were purchased from Sigma Chemicals (St. Louis, MO, USA). 2,3,7,8tetrachlorodibenzo-p-dioxin was purchased from Ultra Scientific (RI, USA). Trizol ${ }^{\mathbb{B}}$ Reagents, was purchased from GibcoBRL Life Technologies (Cergy Pontoise, France). Complete ${ }^{\mathrm{TM}}$ protease inhibitor cocktail tablets and FuGENE 6 transfection reagent were purchased from Roche Diagnostics GmbH (Mannheim, Germany). Secondary horseradish peroxidase conjugated antibody, and Western Blotting Luminol Reagent were purchased from Santa Cruz Biotechnology (Santa Cruz, CA, USA). All other commercially available chemicals were of the highest grade.

\section{Cell cultures}

Human hepatoma cells HepG2 (ECACC No. 85011430) were cultured in Dulbecco's modified Eagle's medium (DMEM) supplemented with $10 \%$ FCS, $100 \mathrm{U} / \mathrm{ml}$ streptomycin, $100 \mu \mathrm{g} / \mathrm{ml}$ penicillin, $4 \mathrm{mM}$ L-glutamine, non-essential amino acids, and $1 \mathrm{mM}$ sodium pyruvate. Cultures were maintained at $37{ }^{\circ} \mathrm{C}$ in $5 \% \mathrm{CO}_{2}$ (air: $\mathrm{CO}_{2}, 95: 5$ ) humidified incubator.

\section{Protein analyses}

HepG2 cells were seeded on 6-well dishes in a density of $1 \times 10^{6}$ cells/well using culture media enriched with fetal calf serum $(10 \% \mathrm{v} / \mathrm{v})$. After $16 \mathrm{~h}$ of stabilization, the medium was exchanged for a serum-free one and the cells were treated $24 \mathrm{~h}$ with dexamethasone (DEX; $100 \mathrm{nM}$ final concentration), 2,3,7,8-tetrachlorodibenzo-p-dioxin (TCDD; $5 \mathrm{nM}$ final concentration), TCDD+DEX and with DMSO as vehicle for control. Total protein extracts were prepared as follows: Cells were washed twice with $1 \mathrm{ml}$ of ice-cold PBS and scraped into $1 \mathrm{ml}$ of PBS. The suspension was centrifuged $\left(1500 \mathrm{~g} / 5 \mathrm{~min} / 4{ }^{\circ} \mathrm{C}\right)$ and the pellet was resuspended in $120 \mu \mathrm{l}$ of ice-cold lysis buffer $(10 \mathrm{mM}$ Hepes $\mathrm{pH} 7.9 ; 10 \mathrm{mM} \mathrm{KCl} ; 1.5 \mathrm{mM} \mathrm{MgCl} 2 ; 0.5 \mathrm{mM}$ DTT; $0.1 \% \mathrm{v} / \mathrm{v}$ NP-40; anti-protease cocktail, $0.2 \% \mathrm{w} / \mathrm{v}$ sodium dodecylsulfate). The mixture was incubated for $20 \mathrm{~min}$ on ice and then centrifuged $(12000 \mathrm{~g} / 10 \mathrm{~min} /$ $4{ }^{\circ} \mathrm{C}$ ). Supernatant was collected and the protein content 
in extracts was determined by the biscinchoninic acid method.

The extracts were analyzed on SDS-PAGE gels (7.5\%) according to the general procedure. Protein transfer onto nitrocellulose membrane was carried out, the membrane was stained with Ponceau S red for control of transfer and then saturated with $8 \%$ non-fat dried milk overnight. Blots were probed with primary antibodies against: human glucocorticoid receptor (sc-1003; GR(E-20)X rabbit polyclonal; dilution 1/1000); aryl hydrocarbon receptor (sc-5579; Ah Receptor (H-211) rabbit polyclonal; dilution 1/500), and $\alpha$-actin (sc-1616; Actin (I-19) goat polyclonal; dilution 1/1000); all purchased from Santa Cruz Biotechnology, Inc. (Santa Cruz, USA). Chemiluminescence detection using horseradish peroxidase conjugated secondary antibodies and an Amersham ECL kit was performed. The intensity of bands after WB analyses was quantified by densitometry.

\section{mRNA analyses}

HepG2 cells were plated on Petri dishes (100 mm I.D.) in a density of $4 \times 10^{6}$ cells/well using culture media enriched with fetal calf serum (10\%v/v). After $16 \mathrm{~h}$ of stabilization, the medium was exchanged for a serum-free one and the cells were treated for $24 \mathrm{~h}$ with dexamethasone (DEX; $100 \mathrm{nM}$ final concentration), 2,3,7,8-tetrachlorodibenzo-p-dioxin (TCDD, $5 \mathrm{nM}$ final concentration), TCDD+DEX and with DMSO as vehicle for control. Total RNA was isolated using Trizol reagent according to the manufacturer's instructions. Concentration of RNA was quantified by spectrometry at $260 \mathrm{~nm}$ and purity was assessed from the ratio of absorbances $\mathrm{A}_{260 \mathrm{~nm}} / \mathrm{A}_{280 \mathrm{~nm}}$. Reverse transcription (RT) was performed on $1 \mu \mathrm{g}$ of total RNA using MMLV reverse transcriptase (Finnnzyme, Espoo, Finland) in a reaction volume of $12 \mu$ containing $1 x$ reaction buffer, $5 \mathrm{mM} \mathrm{MgCl}_{2}, 0.5 \mathrm{mM}$ dNTP mixture, $7.5 \mu \mathrm{M}$ of oligo(dT) ${ }_{18} \mathrm{VN}$ (Generi-Biotech, Hradec Králové, Czech Republic), $1 \mathrm{U} / \mu \mathrm{l}$ of RNase inhibitor TaKaRa (Otsu, Japan), $10 \mathrm{U} / \mu \mathrm{l}$ of MMLV reverse transcriptase, and $1 \mu \mathrm{g}$ of RNA. RT was performed in a thermal Palm-cycler (Corbett Research, Mortlake, Australia) with a profile of $25{ }^{\circ} \mathrm{C}$ for $10 \mathrm{~min}$ and $42{ }^{\circ} \mathrm{C}$ for $70 \mathrm{~min}$. Samples were aliquoted and stored at $-80{ }^{\circ} \mathrm{C}$ until analysis. Real-time PCR was performed using an iCycler (Bio-Rad, Hercules, CA) using SYBR $($ Green chemistry. Mastermix of a volume $25 \mu \mathrm{l}$ contained $0.035 \mathrm{U} / \mu \mathrm{l}$ of HotStart TaqPolymerase (QIAGEN, Valencia, CA), $3 \mathrm{mM} \mathrm{MgCl}_{2}$,
$200 \mathrm{nM}$ fluorescein, 1x buffer, $200 \mathrm{nM}$ dNTP, SybreGreen 1:2500 (Bio-Rad) and $300 \mathrm{nM}$ of each primer. After initial activation of polymerase for $14 \mathrm{~min}$ at $94{ }^{\circ} \mathrm{C}$, samples underwent an additional 40 cycles at $94{ }^{\circ} \mathrm{C}$ for $10 \mathrm{~s}, 60{ }^{\circ} \mathrm{C}$ for $20 \mathrm{~s}$, and $72{ }^{\circ} \mathrm{C}$ for $25 \mathrm{~s}$, followed by a melting curve analysis. Amplicons were visualized using $2 \%$ agarose gel electrophoresis. The primer sequences for hAhR (forward primer 5'-3':TGGACAAGGAATTGAAGAAGC; reverse primer 5'-3':AAAGGAGAGTTTTCTGGAGGAA), for hGR $\alpha$ (forward primer 5'-3':AAACCTTACTGCTTCTCTCT TCA; reverse primer 5'-3':GTTAAGGAGATTTTCAAC CACTTC) and for housekeeping gene hHPRT (forward primer 5'-3':CTGGAAAGAATGTCTTGATTGTGG; reverse primer 5'-3': TTTGGATTATACTGCCTGACC AAG). All samples were run in quadruplicates and CT was automatically calculated. These transcripts were extensively optimized, run simultaneously with RNAand RT-negative controls, and agarose gel electrophoresis was used to confirm the specificity of the priming. Primers were designed using Vector NTI software (Invitrogen). The data were normalized per GAPDH content using delta-delta method. Pfapfl coefficient was considered 2. Statistical calculations were performed in MS Excell using non-pair Student's t-test.

\section{Transfection assays}

The pTAT-(GRE)2-TK-luc plasmid containing two copies of the consensus GRE (glucocorticoid responsive element) upstream of a minimal herpes simplex virus thymidine kinase promoter and a luciferase reporter gene and pTXINV-luc plasmid containing two inverted repeats of the XRE (xenobiotic responsive element) upstream of the thymidine kinase promoter and luciferase reporter gene (Daujat et al. 1996, Backlund et al. 1997) were kindly provided by Dr. L. Poellinger (Karolinska Institute, Stockholm, Sweden). For reporter assays, HepG2 cells were transiently transfected by lipofection (FuGENE 6) with $300 \mathrm{ng}$ of luciferase reporter construct pTAT-(GRE)2-TK-luc or pTXINV-luc. Following $16 \mathrm{~h}$ of stabilization, the medium was exchanged for a serum-free one and the cells were treated in serum free medium for $24 \mathrm{~h}$ with dexamethasone (DEX; $100 \mathrm{nM}$ final concentration), 2,3,7,8tetrachlorodibenzo-p-dioxin (TCDD; $5 \mathrm{nM}$ final concentration), TCDD+DEX and with DMSO as vehicle for control. After the treatments, cells were lysed and luciferase activity was measured and standardized per milligram of protein. 

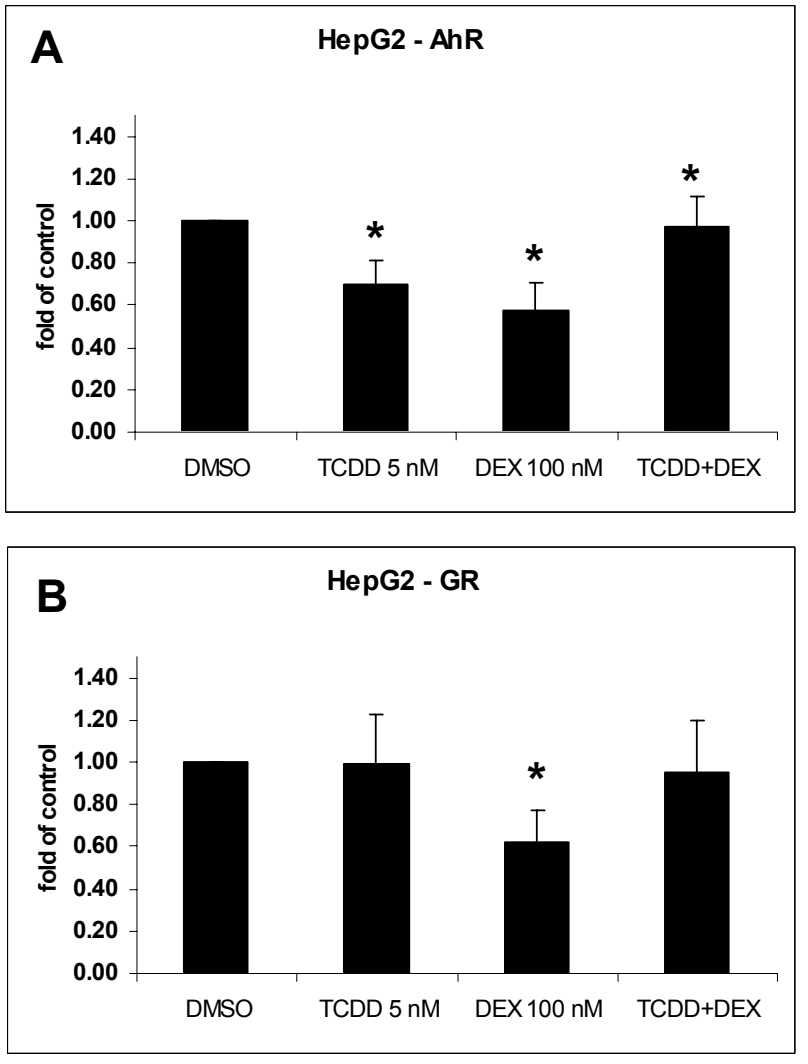

Fig. 1. Effects of DEX and TCDD on AhR and GR mRNAs expression. Cells were treated $24 \mathrm{~h}$ with dexamethasone (DEX; $100 \mathrm{nM}$ final concentration), 2,3,7,8- tetrachlorodibenzo-p-dioxin (TCDD; $5 \mathrm{nM}$ final concentration), TCDD+DEX and with DMSO as vehicle for control. The levels of AhR, GR $\alpha$ and hHPRT mRNAs were determined by RT-PCR as described in the Methods section. The data were normalized on the hHPRT mRNA level. Bar graphs represent means \pm SD of three independent experiments. * - the value significantly different from the control value $(0 \mu \mathrm{M})$ at $\mathrm{p}<0.05$. A. Analyses of AhR mRNA; B. Analyses of $G R \alpha$ mRNA.

\section{EROD assay}

HepG2 cells were plated on 96-well dishes at a density of $2.4 \times 10^{4}$ cells $/ \mathrm{cm}^{2}$ in culture medium supplemented with $10 \%$ FCS and stabilized for $24 \mathrm{~h}$. The medium was exchanged for a serum-free one and the cells were treated for $24 \mathrm{~h}$ with dexamethasone (DEX; $100 \mathrm{nM}$ final concentration), 2,3,7,8-tetrachlorodibenzo-p-dioxin (TCDD; $5 \mathrm{nM}$ final concentration), TCDD+DEX and with DMSO as vehicle for control. The catalytic activity of 7-ethoxyresorufin-O-deethylase (EROD) in cell cultures was measured as described elsewhere (Donato et al. 1993). Briefly, monolayers were washed with PBS and the serum free medium containing $8 \mu \mathrm{M}$ 7-ethoxyresorufin and $10 \mu \mathrm{M}$ dicumarol (to inhibit cytosolic diaphorase) was applied to cells. After $30 \mathrm{~min}$ of incubation at $37^{\circ} \mathrm{C}$, an aliquot of $75 \mu \mathrm{l}$ of the medium was mixed with $125 \mu$ l of methanol and fluorescence was measured in 96-well plate with $530 \mathrm{~nm}$ excitation and
A

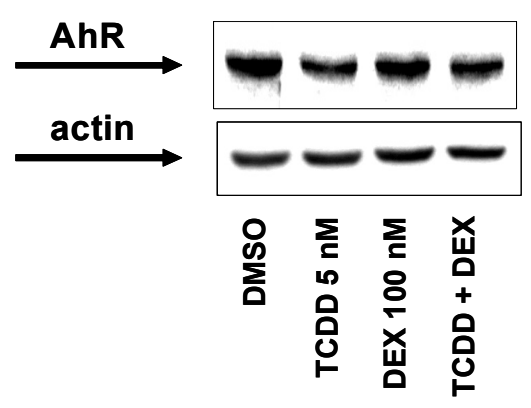

B

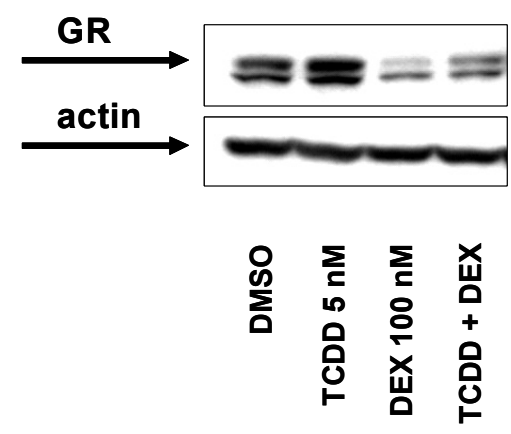

Fig. 2. Effects of DEX and TCDD on AhR and GR proteins levels. Shown are representative Western blots of AhR and GR. Cells were treated $24 \mathrm{~h}$ with dexamethasone (DEX; $100 \mathrm{nM}$ final concentration), 2,3,7,8-tetrachlorodibenzo-p-dioxin (TCDD; $5 \mathrm{nM}$ final concentration), TCDD+DEX and with DMSO as vehicle for control. Total protein extracts were isolated and after western blot analysis the membrane was probed with anti-AhR, anti-GR and anti-actin antibodies. A similar profile was obtained from three independent experiments. A. Analyses of AhR protein; B. Analyses of GR protein.

$590 \mathrm{~nm}$ emission filters. The resorufine formation was linear up to $60 \mathrm{~min}$. The data were expressed as the ratio of treated over control values (DMSO-treated cells).

\section{Statistics}

The results were expressed as means \pm S.D. Student's t-test was applied to all analyses. All calculations were performed using MS Excel 2000.

\section{Results}

\section{Effects of DEX and TCDD on AhR and GR mRNAs} expression

First we analyzed the influence of DEX and TCDD on AhR and GR genes expression. HepG2 cells were treated $24 \mathrm{~h}$ with $100 \mathrm{nM}$ DEX, $5 \mathrm{nM}$ TCDD and/or with mixture of TCDD and DEX. The levels of AhR and 


\section{Table 1.}

\begin{tabular}{lcccccc}
\hline & & \multicolumn{2}{c}{ HepG2 } & & \\
& & GR & & AhR & \\
& DEX & TCDD & T+D & DEX & TCDD & T+D \\
\hline Protein & $\downarrow \downarrow \downarrow$ & $\uparrow$ & $\downarrow \downarrow$ & 0 & $\downarrow \downarrow$ & $\downarrow$ \\
mRNA & $\downarrow$ & 0 & 0 & $\downarrow$ & $\downarrow$ & 0 \\
Reporter assays & $\uparrow$ & $\uparrow$ & $\uparrow \uparrow$ & 0 & $\uparrow \uparrow \uparrow$ & $\uparrow \uparrow$ \\
Enzyme activity of target & NA & NA & NA & $\downarrow$ & $\uparrow \uparrow \uparrow$ & $\uparrow \uparrow$ \\
gene CYP1A1 (EROD) & & & & & & \\
\hline
\end{tabular}

Summary of the effects of TCDD and DEX on GR and AhR protein levels, mRNA levels and transcriptional activities. $\uparrow \uparrow \uparrow=$ strong increase; $\uparrow \uparrow=$ medium increase; $\uparrow=$ weak increase; $\downarrow \downarrow \downarrow=$ strong decrease; $\downarrow \downarrow=$ medium decrease; $\downarrow=$ weak decrease; $0=$ no effect; NA = not applicable.

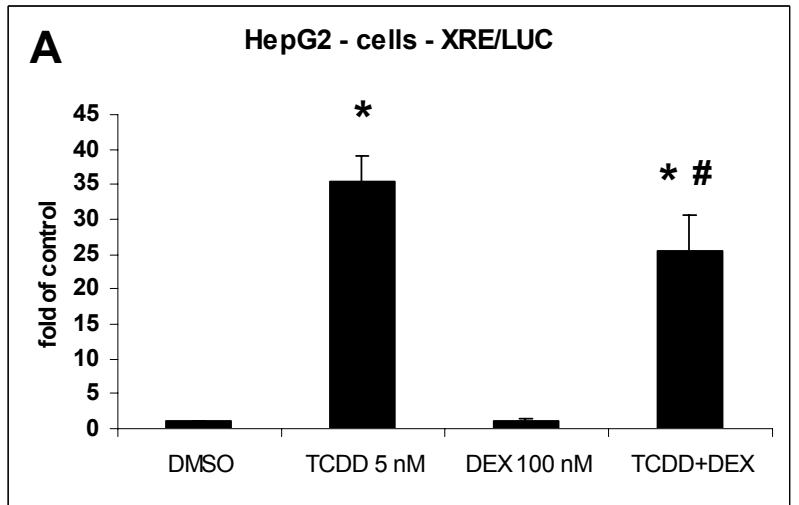

B HepG2 - cells - GRE/LUC

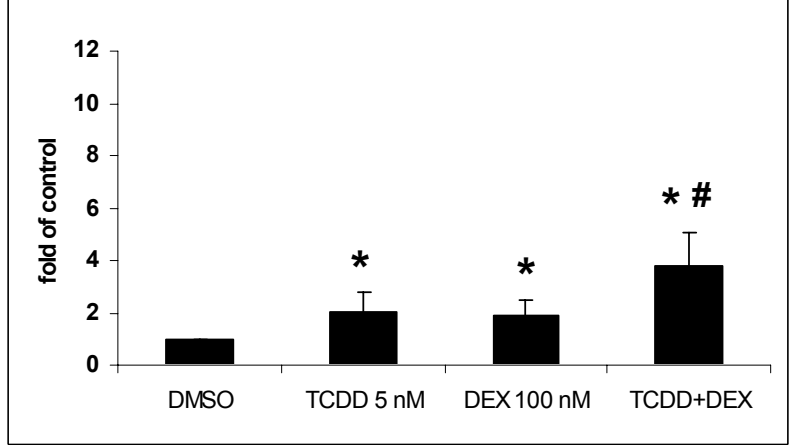

Fig. 3. Effects of DEX and TCDD on AhR and GR transcriptional activities. Bar graphs summarizing the GR and AhR transcriptional activities in transiently transfected HepG2 cells. Cells transfected with pTAT-(GRE)2-TK-luc and/or pTXINV plasmid were incubated for $24 \mathrm{~h}$ with dexamethasone (DEX; $100 \mathrm{nM}$ final concentration), 2,3,7,8-tetrachlorodibenzo-p-dioxin (TCDD; $5 \mathrm{nM}$ final concentration), TCDD+DEX and with DMSO as vehicle for control. The chemiluminescent activities of luciferase reporter genes in cell lysates were measured and normalized to protein concentration. Bar graphs represent the means \pm SD of five independent transfection experiments. In each experiment, six parallel samples were analyzed. * - value is significantly different from the activity of DMSO-treated cells $(p<0.05)$. A. HepG2 cells transfected with pTXINV; \# - value is significantly different from the activity of TCDD-treated cells $(p<0.05) ; \quad B$. HepG2 cells transfected with pTAT-(GRE)2-TK-luc; \# - value is significantly different from the activity of TCDD- and/or DEX-treated cells $(p<0.05)$.
GR mRNAs were analyzed by real-time PCR. Both TCDD and DEX down-regulated AhR mRNA (30-40 \% decrease). Interestingly, combination of DEX + TCDD had only a moderate inhibitory effect on AhR mRNA (5-10\% decrease) (Fig. 1A). TCDD did not alter the levels of GR $\alpha$ mRNA, but DEX diminished the expression of GR $\alpha$ mRNA (40\% decrease). This diminution was reverted when HepG2 cells were incubated with combination of DEX + TCDD (Fig. 1B).

\section{Effects of DEX and TCDD on AhR and GR proteins levels}

While the analyses of AhR and GR mRNAs reveal about the effects of tested substances on gene expression of the two receptors, the analyses of AhR and GR protein content comprise additional information on the stability/degradation of the protein products receptors. HepG2 cells were treated $24 \mathrm{~h}$ with $100 \mathrm{nM}$ DEX, $5 \mathrm{nM}$ TCDD and/or with combination of TCDD and DEX. Total protein extracts were isolated and subjected to Western blot analyses. TCDD caused decrease of AhR protein (about $50 \%$ decrease) (Fig. 2A) probably due to ligand-dependent protein degradation. Interestingly, co-treatment with DEX+TCDD partly reversed the decrease of AhR protein, whereas basal level of AhR was not affected by DEX (Fig. 2A). GR protein was detected in variety of cell lines, however, there are no reports on GR functions and regulation in HepG2 cells. Here, we observed intensive glucocorticoiddependent (by DEX) degradation of GR protein in HepG2 cells (more than $90 \%$ decrease) (Fig. 2B). Cotreatment with DEX+TCDD partly reversed decrease of GR protein by DEX (Fig. 2B). In addition, basal level of GR protein was slightly increased by TCDD. 


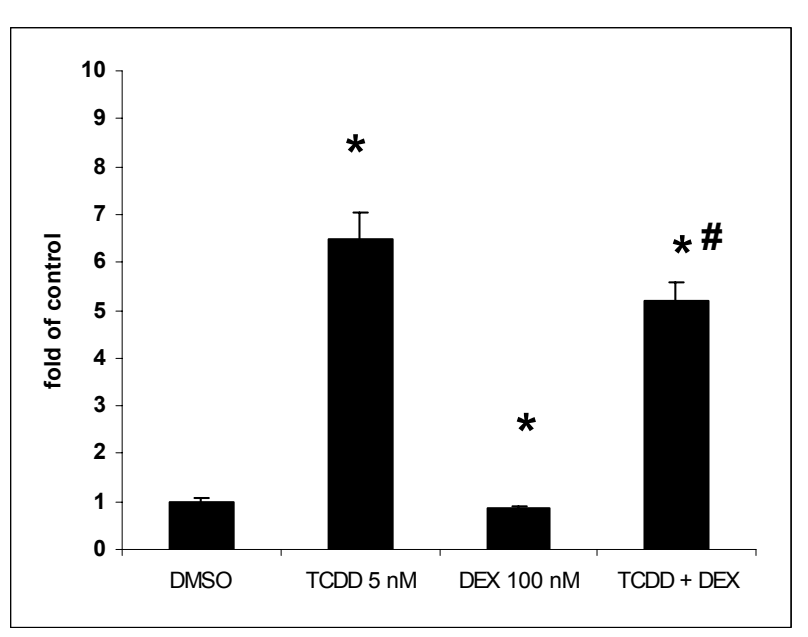

Fig. 4. Effects of DEX and TCDD on EROD activity. HepG2 cells were treated $24 \mathrm{~h}$ with dexamethasone (DEX; $100 \mathrm{nM}$ final concentration), 2,3,7,8- tetrachlorodibenzo-p-dioxin (TCDD; $5 \mathrm{nM}$ final concentration), TCDD+DEX and with DMSO as vehicle for control. CYP1A1 activity (7-ethoxyresorufin-O-deethylase; EROD) was measured by fluorescence spectrophotometry as described in the Methods section. Bar graph represent the means \pm SD of three independent experiments. * - value is significantly different from the activity of DMSO-treated cells $(p<0.05)$; $\#-$ value is significantly different from the activity of TCDD-treated cells $(p<0.05)$.

\section{Effects of DEX and TCDD on AhR and GR transcriptional activities}

HepG2 cells were transiently transfected with pTXINV (XRE-luc; TCDD-responsive) and/or with pTAT-(GRE)2-tkLUC (GRE-luc; glucocorticoidresponsive) reporter plasmids. Following stabilization period, cells were challenged with $100 \mathrm{nM}$ DEX, $5 \mathrm{nM}$ TCDD and/or with mixture of TCDD and DEX for $24 \mathrm{~h}$. Transcriptional activities of GR and AhR receptors were monitored as luciferase activity. Incubation of HepG2 cells transfected with XRE-luc reporter with TCDD resulted in approx. 35 fold induction of AhR-dependent luciferase activity. Dexamethasone did not activate AhRdependent luciferase whereas co-treatment with DEX+TCDD significantly inhibited (about $30 \%$ decrease) TCDD-mediated induction of luciferase (Fig. 3A). Surprisingly, GR-dependent activity of luciferase in HepG2 cells transfected with GRE-luc reporter was induced (approximately twofold induction) not only by glucocorticoid DEX but with similar potency also by TCDD. This effect was significantly augmented when the cells were co-treated with DEX+TCDD (Fig. 3B).

\section{Effects of DEX and TCDD on EROD activity}

Finally, we examined the capability of TCDD and DEX to induce enzymatic activity of AhR-regulated CYP1A1 (EROD activity) in HepG2 cell line. Cells were treated $24 \mathrm{~h}$ with $100 \mathrm{nM}$ DEX, $5 \mathrm{nM}$ TCDD and/or with mixture of TCDD and DEX. TCDD caused an explicit induction of EROD activity (the average increase 6 to 7 fold), whereas DEX had no effect (Fig. 4). Both basal and TCDD-induced EROD activity was diminished by treatment with DEX (about $20 \%$ decrease), which is in accordance with the inhibition of TCDD-dependent AhR transcriptional activation in HepG2 cells by DEX (Fig. 3A).

\section{Discussion}

In present study we bring the evidence that there exists a regulatory cross-talk between cellular signaling by AhR and GR receptors. It is supported in particular by findings that i) dexamethasone (DEX) and dioxin (TCDD) cross-induced the expression of luciferase gene fused to xenobiotic-responsive element (XRE) and glucocorticoid responsive element (GRE), respectively, ii) DEX modulated TCDD-induced transcriptional activity of AhR, iii) DEX modulated TCDD-elicited degradation of AhR protein, and iv) both DEX and TCDD modulates expression of AhR and GR $\alpha$ mRNAs. All the data are summarized in Table 1. In addition, we show that HepG2 cells are equipped with GR protein that is degraded in the presence of the ligand and that GREluc reporter was trans-activated by DEX in HepG2 cells.

Available literary data together with our findings presented here indicate that the interactions between AhR and GR in vitro are determined by several factors. First, there are differences between cellular signaling in normal and transformed cells, because it is well known that transformed cells have often altered signaling pathways and regulatory mechanisms as compared to the normal ones. Second, proliferating and non-proliferating (quiescent) cells differ in cell cycle dependency of AhR (Scholler et al. 1994, Santini et al. 2001, Bonzo et al. 2005) and GR function (Cidlowski and Cidlowski 1982, Hsu et al. 1992, Bodwell et al. 1998, Abel et al. 2002), when stability, transcriptional activity, phosphorylation status and ligand binding capacity of these receptors oscillates throughout cell cycle. Finally, cell type specificity is also of importance.

Apparent discrepancies between the effects of ligands and their combinations on the studied receptors results in certain difficulty of data interpretation. For instance, TCDD down-regulates AhR mRNA in HepG2 
cells (Fig. 1A), simultaneously decreases AhR protein in HepG2 cell (probably also via degradation) (Fig. 2A), but transcriptional activity is progressively increasing (Fig. 3A). Similarly, the interpretation of combined effects of DEX and TCDD should be done with caution. In addition, the effects of DEX, TCDD and their combinations on $\mathrm{AhR}$ and GR mRNAs is rather modulation than robust up-/down-regulation.

Essential question is: Why such an interactive regulation between AhR and GR exists? AhR and GR share several structural and functional features in terms of association of these receptors with chaperones in cytosol, ligand-dependent cytosol to nucleus translocation, proteasome-mediated degradation as negative feedback etc. It has been a dogma for long time, that GR is typical steroid receptor, essential for variety of endogenous functions. However, GR plays important role in regulation of drug-metabolizing enzymes, as it controls expression of PXR, CAR and RXR receptors (Pascussi et al. 1999, 2000a,b). Similarly, the role of AhR receptor in living organisms is ambiguous. It has been considered as xenoreceptor regulating phase I and phase II biotransformation enzymes. In addition, it has been considered as malicious fellow, when its activation (e.g. by exposure to dioxin) leads to a number of toxic effects, in particular to tumor promotion and immune suppression (Barouki and Morel 2001). On the other hand, it is essential factor, because its absence results in severe phenotypic abnormalities (Mimura and Fujii-Kuriyama 2003). In other words, sustained activation of AhR by endogenous ligands is essential for the correct development and functioning of living organisms. The exogenous activation of $\mathrm{AhR}$ is responsible for chemically induced carcinogenesis and other pathological responses. Taken together, both $\mathrm{AhR}$ and GR play important roles in physiological processes and also in drug metabolism or carcinogenesis.

Apart from mechanistic point of view, our data have possible implications in physiology and drug metabolism. Since there exist striking differences between normal and transformed cells, between proliferating and quiescent and cell type specificity in the interactions between $\mathrm{AhR}$ and GR, a future research should be focused on the investigation of AhR-GR crosstalk in normal human cells and tissues both in vitro and in vivo. In this context, the most attractive models for these studies would be human hepatocytes, placental, intestinal, kidney and lung cells and tissues. For instance, based on the presumption that cross-talk exists between AhR and GR, there definitely should be differences in the biological effects of clinically used glucocorticoids in non-smokers and smokers (TCDD-like effects of polycyclic aromatic hydrocarbons). If this is true, it would be alerting issue regarding the massive use of glucocorticoids in asthma, pregnancy, oncology, immunology etc.

\section{Abbreviations}

AhR, Aryl hydrocarbon receptor; BNF, betanaphtoflavone; CAR, constitutive androstane receptor; CYP, cytochrome P450; DEX, dexamethasone; DTT, dithiothreitol; EROD, 7-ethoxyresorufine-O-deethylase; FXR, farnesyl X receptor; GR, glucocorticoid receptor; GRE, glucocorticoid responsive element; HepG2, human hepatoma cells; LXR, liver X receptor; PXR, pregnane X receptor; RU486, mifepristone; RXR, retinoic X receptor; TCDD, 2,3,7,8-tetrachlorodibenzo-p-dioxin; VDR, vitamin D receptor; XRE, xenobiotic-responsive element

\section{Conflict of Interest}

There is no conflict of interest.

\section{Acknowledgements}

This research was supported by grant MSM 6198959216 from the Ministry of Education, Youth and Sports of the Czech Republic and by the grant GACR 303/07/0128 from Grant Agency of the Czech Republic. Authors thank Dr. L. Poellinger (Karolinska Institute, Stockholm, Sweden) for his generous gift of pTAT-(GRE)2-TK-luc and pTXINV reporter plasmids.

\section{References}

ABBOTT BD: Review of the interaction between TCDD and glucocorticoids in embryonic palate. Toxicology 105 : 365-373, 1995.

ABBOTT BD, PERDEW GH, BUCKALEW AR, BIRNBAUM LS: Interactive regulation of Ah and glucocorticoid receptors in the synergistic induction of cleft palate by 2,3,7,8-tetrachlorodibenzo-p-dioxin and hydrocortisone. Toxicol Appl Pharmacol 128: 138-150, 1994. 
ABBOTT BD, PROBST MR, PERDEW GH, BUCKALEW AR: AH receptor, ARNT, glucocorticoid receptor, EGF receptor, EGF, TGF alpha, TGF beta 1, TGF beta 2, and TGF beta 3 expression in human embryonic palate, and effects of 2,3,7,8-tetrachlorodibenzo-p-dioxin (TCDD). Teratology 58: 30-43, 1998.

ABBOTT BD, SCHMID JE, BROWN JG, WOOD CR, WHITE RD, BUCKALEW AR, HELD GA: RT-PCR quantification of AHR, ARNT, GR, and CYP1A1 mRNA in craniofacial tissues of embryonic mice exposed to 2,3,7,8-tetrachlorodibenzo-p-dioxin and hydrocortisone. Toxicol Sci 47: 76-85, 1999.

ABEL GA, WOCHNIK GM, RUEGG J, ROUYER A, HOLSBOER F, REIN T: Activity of the GR in G2 and mitosis. Mol Endocrinol 16: 1352-1366, 2002.

ALURU N, RENAUD R, LEATHERLAND JF, VIJAYAN MM: Ah Receptor-mediated impairment of interrenal steroidogenesis involves StAR protein and P450scc gene attenuation in rainbow trout. Toxicol Sci 84: 260-269, 2005.

ALURU N, VIJAYAN MM: beta-Naphthoflavone disrupts cortisol production and liver glucocorticoid responsiveness in rainbow trout. Aquat Toxicol 67: 273-285, 2004.

BACKLUND M, JOHANSSON I, MKRTCHIAN S, INGELMAN-SUNDBERG M: Signal transduction-mediated activation of the aryl hydrocarbon receptor in rat hepatoma H4IIE cells. J Biol Chem 272: 31755-31763, 1997.

BAROUKI R, MOREL Y: Repression of cytochrome P450 1A1 gene expression by oxidative stress: mechanisms and biological implications. Biochem Pharmacol 61: 511-516, 2001.

BODWELL JE, WEBSTER JC, JEWELL CM, CIDLOWSKI JA, HU JM, MUNCK A: Glucocorticoid receptor phosphorylation: overview, function and cell cycle-dependence. J Steroid Biochem Mol Biol 65: 91-99, 1998.

BONZO JA, CHEN S, GALIJATOVIC A, TUKEY RH: Arsenite inhibition of CYP1A1 induction by 2,3,7,8tetrachlorodibenzo-p-dioxin is independent of cell cycle arrest. Mol Pharmacol 67: 1247-1256, 2005.

BRAKE PB, ZHANG L, JEFCOATE CR: Aryl hydrocarbon receptor regulation of cytochrome P4501B1 in rat mammary fibroblasts: evidence for transcriptional repression by glucocorticoids. Mol Pharmacol 54: 825-833, 1998.

CELANDER M, HAHN ME, STEGEMAN JJ: Cytochromes P450 (CYP) in the Poeciliopsis lucida hepatocellular carcinoma cell line (PLHC-1): dose- and time-dependent glucocorticoid potentiation of CYP1A induction without induction of CYP3A. Arch Biochem Biophys 329: 113-122, 1996.

CIDLOWSKI JA, CIDLOWSKI NB: Glucocorticoid receptors and the cell cycle: evidence that the accumulation of glucocorticoid receptors during the $\mathrm{S}$ phase of the cell cycle is dependent on ribonucleic acid and protein synthesis. Endocrinology 110: 1653-1662, 1982.

CSABA G, MAG O, INCZEFI-GONDA A, SZEBERENYI S: Persistent influence of neonatal 2,3,7,8tetrachlorodibenzo-p-dioxin (TCDD) treatment on glucocorticoid receptors and on the microsomal enzyme system. J Dev Physiol 15: 337-340, 1991.

CUTHILL S, POELLINGER L, GUSTAFSSON JA: The receptor for 2,3,7,8-tetrachlorodibenzo-p-dioxin in the mouse hepatoma cell line Hepa 1c1c7. A comparison with the glucocorticoid receptor and the mouse and rat hepatic dioxin receptors. J Biol Chem 262: 3477-3481, 1987.

DAUJAT M, CHARRASSE S, FABRE I, LESCA P, JOUNAIDI Y, LARROQUE C, POELLINGER L, MAUREL P: Induction of CYP1A1 gene by benzimidazole derivatives during Caco-2 cell differentiation. Evidence for an aryl-hydrocarbon receptor-mediated mechanism. Eur J Biochem 237: 642-652, 1996.

DENIS M, CUTHILL S, WIKSTROM AC, POELLINGER L, GUSTAFSSON JA: Association of the dioxin receptor with the Mr 90,000 heat shock protein: a structural kinship with the glucocorticoid receptor. Biochem Biophys Res Commun 155: 801-807, 1988.

DENIS M, WILHELMSSON A, CUTHILL S, POELLINGER L, GUSTAFSSON JA: Structural differences between the glucocorticoid, dioxin and oxysterol receptors from rat liver cytosol. Biochem Biophys Res Commun 163: 444-451, 1989.

DONATO MT, GOMEZ-LECHON MJ, CASTELL JV: A microassay for measuring cytochrome P450IA1 and P450IIB1 activities in intact human and rat hepatocytes cultured on 96-well plates. Anal Biochem 213: 29-33, 1993.

DVOŘÁK Z, ULRICHOVÁ J, MODRIANSKÝ M: Role of microtubules network in CYP genes expression. Curr Drug Metab 6: 545-552, 2005a. 
DVOŘÁK Z, ULRICHOVÁ J, MODRIANSKÝ M: Role of microtubules network in CYP genes expression. Curr Drug Metab 6: 545-552, 2005b.

HINES RN, MATHIS JM, JACOB CS: Identification of multiple regulatory elements on the human cytochrome P450IA1 gene. Carcinogenesis 9: 1599-1605, 1988.

HSU SC, QI M, DEFRANCO DB: Cell cycle regulation of glucocorticoid receptor function. EMBO J 11: 3457-3468, 1992.

LAI KP, WONG MH, WONG CK: Modulation of AhR-mediated CYP1A1 mRNA and EROD activities by 17betaestradiol and dexamethasone in TCDD-induced H411E cells. Toxicol Sci 78: 41-49, 2004.

LIN FH, STOHS SJ, BIRNBAUM LS, CLARK G, LUCIER GW, GOLDSTEIN JA: The effects of 2,3,7,8tetrachlorodibenzo-p-dioxin (TCDD) on the hepatic estrogen and glucocorticoid receptors in congenic strains of Ah responsive and Ah nonresponsive C57BL/6J mice. Toxicol Appl Pharmacol 108: 129-139, 1991.

MATHIS JM, PROUGH RA, HINES RN, BRESNICK E, SIMPSON ER: Regulation of cytochrome P-450c by glucocorticoids and polycyclic aromatic hydrocarbons in cultured fetal rat hepatocytes. Arch Biochem Biophys 246: 439-448, 1986a.

MATHIS JM, PROUGH RA, SIMPSON ER: Synergistic induction of monooxygenase activity by glucocorticoids and polycyclic aromatic hydrocarbons in human fetal hepatocytes in primary monolayer culture. Arch Biochem Biophys 244: 650-661, 1986b.

MIMURA J, FUJII-KURIYAMA Y: Functional role of AhR in the expression of toxic effects by TCDD. Biochim Biophys Acta 1619: 263-268, 2003.

MIZUYACHI K, SON DS, ROZMAN KK, TERRANOVA PF: Alteration in ovarian gene expression in response to 2,3,7,8-tetrachlorodibenzo-p-dioxin: reduction of cyclooxygenase-2 in the blockage of ovulation. Reprod Toxicol 16: 299-307, 2002.

PASCUSSI JM, JOUNAIDI Y, DROCOURT L, DOMERGUE J, BALABAUD C, MAUREL P, VILAREM MJ: Evidence for the presence of a functional pregnane $\mathrm{X}$ receptor response element in the CYP3A7 promoter gene. Biochem Biophys Res Commun 260: 377-381, 1999.

PASCUSSI JM, DROCOURT L, FABRE JM, MAUREL P, VILAREM MJ: Dexamethasone induces pregnane X receptor and retinoid $\mathrm{X}$ receptor-alpha expression in human hepatocytes: synergistic increase of CYP3A4 induction by pregnane X receptor activators. Mol Pharmacol 58: 361-372, 2000a.

PASCUSSI JM, GERBAL-CHALOIN S, FABRE JM, MAUREL P, VILAREM MJ: Dexamethasone enhances constitutive androstane receptor expression in human hepatocytes: consequences on cytochrome P450 gene regulation. Mol Pharmacol 58: 1441-1450, 2000b.

PASCUSSI JM, DVOŘÁK Z, GERBAL-CHALOIN S, ASSENAT E, MAUREL P, VILAREM MJ: Pathophysiological factors affecting CAR gene expression. Drug Metab Rev 35: 255-268, 2003.

PASCUSSI JM, DVOŘÁK, Z., GERBAL-CHALOIN, S., ASSENAT, E., DROCOURT, L., MAUREL, P., VILAREM, M.J. Regulation of xenobiotic detoxification by PXR, CAR, GR, VDR and SHP receptors: Consequences in physiology. In: Transcription Factors, STARKE K, (ed), Springer-Verlag, Berlin, 2004, pp 409-435.

PASCUSSI JM, GERBAL-CHALOIN S, DROCOURT L, ASSENAT E, LARREY D, PICHARD-GARCIA L, VILAREM MJ, MAUREL P: Cross-talk between xenobiotic detoxication and other signalling pathways: clinical and toxicological consequences. Xenobiotica 34: 633-664, 2004.

PRATT RM: Receptor-dependent mechanisms of glucocorticoid and dioxin-induced cleft palate. Environ Health Perspect 61: 35-40, 1985.

SANTINI RP, MYRAND S, ELFERINK C, REINERS JJ, JR.: Regulation of Cyp1a1 induction by dioxin as a function of cell cycle phase. J Pharmacol Exp Ther 299: 718-728, 2001.

SCHOLLER A, HONG NJ, BISCHER P, REINERS JJ, JR.: Short and long term effects of cytoskeleton-disrupting drugs on cytochrome P450 Cyp1a-1 induction in murine hepatoma 1c1c7 cells: suppression by the microtubule inhibitor nocodazole. Mol Pharmacol 45: 944-954, 1994. 